\title{
Acute Flaccid Paralysis due to Japanese Encephalitis: A Case Report
}

\author{
S Monira Hussain ${ }^{1}$, A R M Saifuddin Ekram ${ }^{2}$, M Jahangir Hossain ${ }^{3}$ \\ M A K Azad ${ }^{4}$, A B Siddiqui ${ }^{5}$, I Ahmed
}

\begin{abstract}
An eleven-year-old boy came to Department of Paediatrics of Rajshahi Medical College Hospital with fever and unconsciousness. His pupillary light reflexes were bilaterally sluggish, all the deep tendon reflexes were diminished, and planter reflexes were bilaterally flexor. His left leg become paralyzed on $13^{\text {th }}$ day and by $15^{\text {th }}$ day all his limbs became paralyzed. Besides these, the patient had gross muscle wasting but his deep tendon reflexes were diminished. The patient was proved to have Japanese encephalitis infection by a four-fold rise in virus-specific antibody detected in paired acute and convalescent sera by enzyme-linked immunosorbant assay.
\end{abstract}

TAJ 2005; 18(1): 47-48

\section{Introduction}

Japanese encephalitis is common mosquito-borne viral encephalitis found in Asia causing significant morbidity and mortality. Japanese encephalitis virus is transmitted in a zoonotic cycle among mosquitoes and vertebrate-amplifying hosts, chiefly pigs and wading birds. Humans become infected coincidentally when living or traveling in close proximity to the enzootic cycle of the virus. Onset of encephalitis can be abrupt, acute, sub acute, or gradual. The course of the disease can be divided into three stages: a prodromal stage, an encephalitic stage and a late stage noticeable by recovery or persistence of signs of CNS injury. High grade fever with or without rigors, headache, general malaise, nausea, vomiting followed by altered sensorium, convulsions, neck stiffness, muscular rigidity, mask-like facies, and abnormal movements are the classic clinical picture of the disease. Apart from the classical presentation other atypical presentations of JE have been reported. Among them an acute flaccid paralysis-like illness has recently been reported and this is a rare one. Here we describe an 11-year-old boy presented with fever, unconsciousness and acute flaccid paralysis.

\section{Case report}

An eleven year old hailing from Rohonpur, Chapainababgonj of Bangladesh came to Paediatrics Department of Rajshahi Medical College Hospital with the complaints of fever, cough, headache, hallucination, drowsiness for 5 days. He developed convulsion, which lasted for 2 days, and for the last three days the patient was unconscious. On admission his temperature was $100^{\circ} \mathrm{F}$, pulse rate $80 / \mathrm{min}$, respiratory rate $16 / \mathrm{min}$, B.P. $100 / 70 \mathrm{~mm}$ of $\mathrm{Hg}$ and no abnormality was detected in his heart, lungs or abdomen. He had no tremor or rigidity, scored 04 in Glasgow Coma Scale Scoring, his neck was free, pupillary light

\footnotetext{
1 Project Research Physician, HSID, ICDDR, B, Mohakhali, Dhakd-1212, Bangladesh.

2 Professor, Department of Medicine, Rajshahi Medical College, Rajshahi-6000, Bangladesh.

${ }^{3}$ Assistant Scientist, HSID, ICDDR, B, Mohakhali, Dhaka-1212, Bangladesh.

${ }^{4}$ Director, Rajshahi Medical College Hospital, Rajshahi-6000, Bangladesh.

5 Professor, Department of Paediatrics, Rajshahi Medical College, Rajshahi-6000, Bangladesh.

${ }^{6}$ Professor, Department of Microbiology, Rajshahi Medical College, Rajshahi-6000, Bangladesh.
} 
reflexes were bilaterally sluggish, all the deep tendon reflexes were diminished, his planter reflex was flexor bilaterally. After three days of admission the patient started to regain consciousness and from seventh day he started to stare at, in the ninth day weakness in his left leg was noticed, weakness involved his left hand and right leg by $13^{\text {th }}$ day and his left leg was paralyzed by this time, right leg also become paralyzed after one day. On $15^{\text {th }}$ day all his limbs become paralyzed. In these 15 days the patient had gross muscle wasting but his deep tendon reflexes were diminished like the very first day and he had no strength to move his limbs. He used to stare in vacant eyes. After 6 weeks from being hospitalized in RMCH the patient was looked for follow-up visit. But the patient was dead prior to three days of the follow-up visit.

On the $2^{\text {nd }}$ day of admission his WBC were 11,000 cells/cmm with neutrophilic leucocytosis; ESR $44 \mathrm{~mm}$ in the $1^{\text {st }}$ hour in Westergren method; the patient had hyponatraemia, which was corrected. CSF opening pressure, 34cells/cmm of which $90 \%$ were lymphocytes and $10 \%$ were polymorphs, protein $51 \mathrm{mg} / \mathrm{dl}$ and glucose $48.6 \mathrm{mg} / \mathrm{dl}$. Japanese encephalitis infection was demonstrated by a fourfold rise in virus-specific antibody detected in paired acute and convalescent sera enzyme-linked immunosorbant assay.

\section{Discussion}

Acute flaccid paralysis caused by Japanese encephalitis virus infection is a rare phenomenon. Japanese encephalitis is an important public health problem. Because it is almost impossible to eradicate the disease and the graphical area affected by JE is expanding. ${ }^{1}$ Recent discovery of poliomyelitis-like presentation of Japanese encephalitis virus in Vietnam rose a panic. $^{2}$ Japanese encephalitis infection has not been recognized in Bangladesh since an outbreak in 1977 Madhupur near Mymensingh ${ }^{3}$. No new cases were documented in that area for two years following the outbreak. The outbreak was thought to be due to local introduction of the virus from an endemic area. $^{4}$ a prospective hospital-based surveillance study carried out by Centre for Health and Population Research (ICDDR,B) and the Centers for Disease Control and Prevention (CDC) in Atlanta and Ft. Collins, USA began in June 2003 at Dhaka, Mymensingh and Rajshahi Medical College Hospital to find out the causes of encephalitis proved that there are $6 \%$ patient who were admitted to the hospitals with the signs and symptoms of encephalitis were infected with $\mathrm{JE}^{4}$ In Rajshahi Medical College Hospital 12.38\% patients admitted from mainly from three districts of Rajshahi division which are bordered by India where JEV is endemic had Japanese encephalitis infection. ${ }^{56}$ This patient is from one of those three districts. Japanese encephalitis infection was demonstrated by a four-fold rise in virus-specific antibody detected in paired acute and convalescent sera by enzyme-linked immunosorbant assay testing and subsequent plaque reduction neutralizing testing for virus specificity of the antibody. For detecting whether it is a recent or previous infection both IgM and IgG antibody was observed and in serum sample only IgM antibody was found which proves that it was a recent infection.

\section{References}

1. Solomon T, Dung NM, Kneen R, Gainsborough M, Vaughn DW, Khanh VT. Japanese encephalitis. J Neurol Neurosurg Psychiatry 2000; 68: 405-415.

2. Solomon T, Kneen R, Dung NM, et al. Poliomyelitislike illness due to Japanese encephalitis virus. Lancet 1998; 351: 1094-1097.

3. Khan AM, Khan AQ, Dobrzynski L, Joshi GP, Myat A. A Japanese encephalitis focus in Bangladesh. $J$ Trop Med Hyg 1981; 84: 41-4.

4. Surveillance for encephalitis in Bangladesh: preliminary results; Health and Sci Bull, December 2004, vol. 2 no. 4; 7-11.

5. Hussain SM, Ekram ARMS, Hossain MJ et al. Preliminary report of encephalitis surveillance study in Rajshahi Medical College Hospital. (In press).

6. Chatterjee S, Chattopadhyay D, Bhattacharya MK, Mukherjee B. Serosurveillance for Japanese encephalitis in children in several districts of West Bengal, India: Acta Paediatr. 2004 Mar; 93(3): 390-3. 